\title{
High-performance work systems and employee voice behaviour: An integrated model and research agenda
}

\author{
by
}

\author{
Paula K. Mowbray, Adrian Wilkinson and Herman H.M. Tse
}

Accepted for publication Personnel Review (October 09, 2020)

\begin{abstract}
Purpose -The purpose of this paper is to develop a conceptual model drawing together and integrating research from employment relations (ER), human resource management (HRM) and organizational behaviour (OB) to identify how highperformance work systems (HPWS) encourage voice behaviour.
\end{abstract}

Design/methodology/approach - The authors identify shortcomings in research on the relationship between HPWS practices and employee voice behaviour, attributable to the disparate conceptualization of voice across management disciplines. The authors then present a conceptual model using the ability, motivation and opportunity (AMO) framework to theorize how the ER climate influences the design of the HPWS and subsequently how the HPWS encourages voice behaviour. Practical implications and recommendations for future studies are provided.

Findings -The mutual gains ER climate will influence the design of the HPWS; in turn the HPWS' practices will influence line manager AMO to manage voice and the employees' AMO to engage in voice behaviour, resulting in the encouragement of both employer and employee interest forms of voice.

Practical implications - The HPWS-voice behaviour interaction model sheds light on the types of HR practices organizations can implement to optimize employee voice behaviour.

Originality/value - The conceptual model demonstrates how ER, HRM and OB factors influence voice behaviour within a HPWS, which has not previously been considered by voice scholars. The integrated conceptual model encourages a multidisciplinary approach to studying employee voice in future research.

Keywords - Employee Voice, High-Performance Work Systems, Strategic HRM, Line Managers, Employee Involvement

Paper type - Conceptual paper 


\section{Introduction}

Despite a general consensus that voice is largely about the expression of concerns, suggestions, ideas and opinions (Morrison, 2014) and the ability of employees "to have a say" (Wilkinson et al., 2014, p.5), different conceptualizations and foci of voice have evolved between the different management disciplines, including the organizational behaviour (OB), human resource management (HRM) and employment relations (ER) fields (see the following reviews: Kaufman, 2015a; Mowbray et al., 2015; Barry and Wilkinson, 2016; Knoll et al., 2016). This siloed approach to examining employee voice has resulted in a significant gap in the overall employee voice literature, whereby we know much about the psychological antecedents to informal, individual employee voice behaviour (Chamberlin et al. 2017), the different types of formal employee voice mechanisms (Marchington, 2007) and the role of unions in creating collective voice (Budd, 2004), but we know little about the relationships between each of these (i.e. how formal voice mechanisms and ER, or even other HR practices, influences employee voice behaviour (Morrison, 2014). This paper goes some way toward addressing that gap by proposing an integrative conceptual model that illustrates how employee voice behaviour can be facilitated within a high-performance work system (HPWS), whereby a suite of HR practices and voice mechanisms, alongside the ER climate, influence voice behaviour. In short, most work on voice is bifurcated: either located within ER and about collective voice and ignoring individual voice OR located within OB/HRM and very much about individual voice behaviour but ignoring voice systems and collective voice. We use HPWS as a bridge to build a model of voice which incorporates both and which illuminates the links and relationships for both these bodies of work within a single model. 
Employee voice is considered an integral component of HPWS (Wood and Wall, 2007; Budd et al., 2010), based on the premise that the opportunity for employees to be involved in decision-making will contribute to organizational performance (Becker and Gerhart, 1996; Guest, 1997; Boxall and Purcell, 2011). Central to the HPWS literature is the tenet that voice opportunity alone does not lead to performance. Rather, it is a bundle of HR practices (MacDuffie, 1995), including ability-enhancing practices such as selective recruitment, extensive training and development, along with motivationenhancing practices, such as performance related pay and rewards, merit based promotion systems and appraisals, which together with voice opportunities enabled through empowerment programs, formal participation programs and regular information sharing initiatives, provide the ability, motivation and opportunity (AMO) to increase employees' knowledge, skills and abilities and subsequent improved performance (Becker and Huselid, 1998; Appelbaum et al., 2000; Combs et al, 2006; Jiang et al. 2012; Kehoe and Wright, 2013). In this paper, we propose there may be a cumulative effect of these practices on employee voice behaviour i.e. it is not just the opportunity-enhancing practices that will influence voice. Rather, the HR practices associated with motivation and ability will also play a key role in encouraging voice behaviour.

Surprisingly, however, within HPWS' studies there is little explanation for how the other HR practices influence voice behaviour. In their meta-analysis of voice antecedents, Chamberlin et al. (2017) found opportunity-enhancing practices increased employee voice, however the influence of other HR practices was not identified. Therefore, in our paper we make an important contribution to the voice literature by theorizing how the bundle of AMO-enhancing HR practices that constitute a HPWS can enhance the opportunities provided by the voice mechanisms to encourage voice 
behaviour. In doing so, we take a rare integrated approach to voice drawing from ER, HRM and OB concepts of voice i.e. prosocial, constructive voice that is organizationfocused, such as process improvements, i.e. employer interests, as well as voice related to employee interests, such as wages and working conditions.

Our integrated conceptual model makes three key contributions to the employee voice literature. First, we respond to the repeated calls by scholars (Pohler and Luchak, 2014; Kaufman, 2015a; Mowbray et al., 2015; Barry and Wilkinson, 2016; Knoll et al., 2016) to integrate the diverse voice literatures by developing a model that illustrates how, within the context of a HPWS and mutual-gains ER climate, HR practices and formal voice mechanisms influences employer and employee-interest voice behaviour. In short, we draw on the combined lens of ER, HRM and OB to provide a greater understanding of the combined effect of systems and leaders on voice behaviour.

Second, our integrated model illustrates how formal voice mechanisms, along with other HR practices and the ER climate, interact with employee voice behaviour constructs that have typically been associated with informal voice in the OB literature, such as leadership traits and styles (see Morrison, 2011, 2014 for exhaustive reviews). Formal voice has often been neglected within OB voice studies, given this group of scholars conceptualise voice as an informal discretionary behaviour (Van Dyne and LePine 1998). However, both formal and informal voice behaviour may be subject to similar influences from leaders and HR practices, which warrants future consideration by voice scholars. In doing so, this paper will provide new insights into the integration of both voice conceptualisations and suggest new directions for future research

Third, we contribute to both the employee voice and HPWS literature by showing how HR practices play a key role in influencing the line manager in their management of 
employee voice and the employee in their voice behaviour, through the HR practices' AMO voice-enhancing properties (Blumberg and Pringle, 1982). In Wood's (2011) examination of seminal studies on high involvement management practices (which incorporate practices commonly associated with HPWS), he highlighted disparate findings showing a link between these practices and performance, although there were strong links between opportunities to voice and performance. He therefore called for greater theorization to understand how practices, such as training and teamwork, may together contribute to performance. While our focus in this paper is not on the link between HPWS and performance, we do theorize how various HR practices will work together to optimize employee voice behaviour. Hence, we highlight an alternative theoretical pathway through which the cumulative effect of HPWS practices may impact performance i.e. through its optimizing effect on employee voice.

We proceed by presenting our HPWS-voice behaviour interaction model. In doing so, we draw on empirical evidence from the ER, HRM and OB voice literature, and HPWS literature, and make propositions concerning likely relationships. Finally, we identify practical implications and then make suggestions for future research that will advance the employee voice literature.

\section{Integrated model of employee voice systems and behaviour within HPWS}

It is important to note that unlike most papers which examine HPWS within the context of performance outcomes (for example, Do et al., 2019; Siddique et al., 2019), our focus here is not on performance; rather, voice behaviour as an outcome of the HPWS practices. Applying the AMO framework (Blumberg and Pringle, 1982) to our model (see Figure 1), we are able to examine not only how the opportunity-enhancing practices influence voice behaviour, but also to further extrapolate how the ability- 
enhancing and motivation-enhancing practices within the HPWS can influence voice behaviour. We also consider how the ER climate within the context of a HPWS influences voice behaviour. Hence, the aim of this conceptual model is to illustrate how ER, HR and OB perspectives and literatures of employee voice and HPWS can be incorporated to better explain how employee voice can be optimized. Our secondary aim is to provide a novel theoretical contribution concerning how the AMO-enhancing HR practices within a HPWS can influence voice outcomes. Conceptual models such as this are important in order to set out an agenda for future integrated studies on employee voice. There is widespread acceptance that researchers in the voice arena have much to learn from each other but while this has been a familiar call to arms, it is also noteworthy that there are few doing the integration even while many call for it (Wilkinson et al., 2020).

Before we begin discussing the detail of the model, it is important to reiterate that to date, research concerning the relationship between HPWS and employee voice has focused primarily on the ways HPWS provide opportunities to voice. According to Harley (2020), voice occurs within a HPWS via three means, including the presence of high autonomy jobs, where employees have a high level of discretion concerning production processes; second, autonomous or semi-autonomous work teams, where employees have input to team decisions about production; and third, the inclusion of mainstream voice mechanisms, such as suggestions schemes. Each of these encourages a continuous improvement culture and provides formal avenues for organizationfocused voice, such as problem-solving groups, team meetings, self-managed teams and information sharing forums (Huselid 1995; Combs et al. 2006). The relationship between HPWS and voice opportunity is well established in the literature (Harley, 2020), so we make no claim in this regard to a novel contribution. However, its 
inclusion in the model is important as we propose that along with these opportunityenhancing practices, ability and motivation-enhancing practices within the HPWS will also have effects on both managers and employees and subsequent voice behaviour, which we explore in the following discussion.

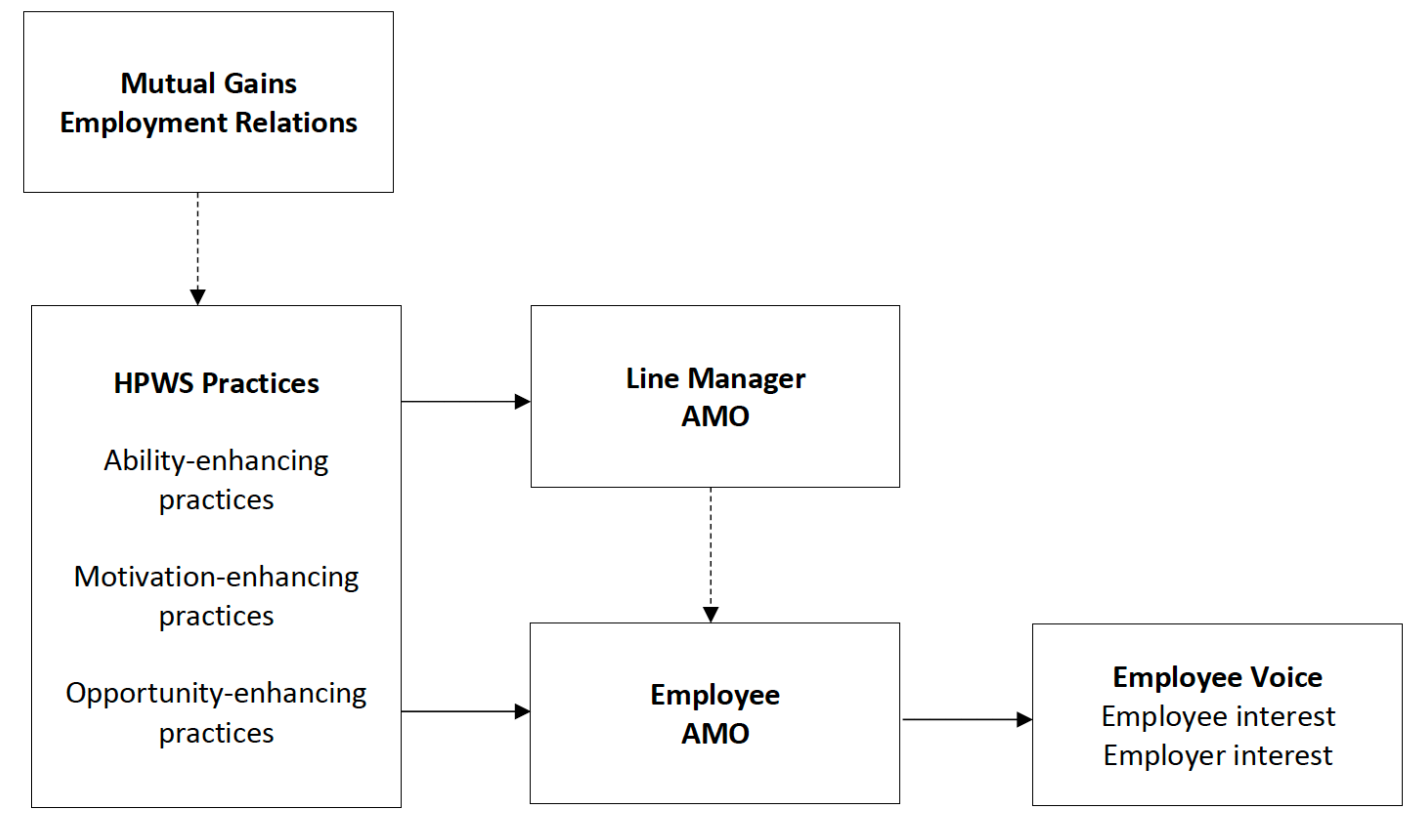

Figure 1 HPWS-Voice Behaviour Model

\section{Mutual Gains Employment Relations}

We begin our discussion of the model with a consideration of how the ER climate influences employee voice within a HPWS. When characterized by a cooperative relationship between the union and organization, this can lead to mutual gains i.e. improved productivity and enhanced quality of working life (Harley, 2020; Jo et al., 2020). Research indicates in a mutual gains environment, unionized workplaces can enhance the implementation and outcomes of the HPWS, (see for example: Gill, 2009; Pyman et al., 2010; Gill and Meyer, 2013; Vernon and Brewster, 2013; MacKenzie et al. 2015; Cook et al., 2017). It follows then, that workplaces with a HPWS and a mutual 
gains ER arrangement may provide greater opportunities for employees to express organization and employee-focused voice, as there will be pressure on the organization to design voice mechanisms that facilitate both forms of voice.

Laroche and Salesina (2017) found positive effects of employee representation on variable compensation and employee participation practices within HPWS organizations, thus providing greater levels of workplace democracy. Therefore, another argument offered in favour of union influence over HPWS is that the system will be more reflective of workers' preferences and the HR practices will be more likely to improve workers' motivation, through a 'collective voice/institutional response dynamics' (Laroche and Salesina, 2017, p. 178). An explanation for this positive union and HPWS relationship can be found in Newman et al.'s (2019) study which identified that a positive union influence increased employees' trust in management, an important precursor to voice (Hu and Jiang, 2018).

Alternatively, non-union employee representation (NER) voice mechanisms can operate alongside the direct voice mechanisms within the HPWS (or act as a hybrid model in unionized workplaces) and also promote mutually beneficial interests. Gollan et al. (2015) discuss the need for both employers and employees to commit to a longterm mutual gain strategy when investing in NER, by providing employees with training, job security and gainsharing, in order to create trust and build employee commitment (see also Kaufman, 2015b).

Therefore, we see that a mutual gains ER climate will have an influence over voice behaviour, starting with the design of the HPWS and inclusion of voice mechanisms that provide the opportunity to voice on organization and employee interests (Saridakis et al., 2017); second, through HR practices that support and motivate employees to 
voice (de Prins et al., 2020); and third, by signalling to employees they can trust their organization (Pyman et al., 2006). Given trust has already been identified as an antecedent to informal voice behaviour (Gao et al., 2011), we propose then that under this arrangement, employees will be more likely to voice on both organization and employee interests.

\section{Line Manager AMO}

We know from the extant HR research that the line manager plays a significant role in implementing the organization's HR practices and in the people management of their team, and thus there is likely to be variability within and across organizations with respect to how those HR practices are implemented by the line manager on the basis of their skills and motivation (Purcell and Hutchinson, 2007; Bos-Nehles et al., 2013). If there is a lack of visibility, consensus and consistency in how the practices have been implemented by the line manager (Bowen and Ostroff, 2004), it is likely that the actual HR practices will be experienced differently by employees within the same organization (Alfes et al., 2020). In this section, we discuss how the HPWS can improve line managers' management of voice and implementation of practices through changes to line manager AMO.

The involvement of line managers in the successful implementation of HR practices, or otherwise, is very much dependent upon the inclination of the line manager to be involved in HR duties (their motivation) and their own ability to do so (FentonO’Creevy, 1998, 2001; Larsen and Brewster, 2003; Watson et al., 2006; Purcell and Hutchinson, 2007). Applying AMO theory to line managers, Bos Nehles et al. (2013) found that ability was the most important variable contributing to line managers successfully managing HRM, and this was enhanced by opportunity. Similarly, Van 
Waeyenberg and Decramer (2018) found that line manager AMO was related to the successful implementation of performance management practices, while McGovern et al. (1997) found that ensuring performance targets were met were a significant motivator in line managers' HR implementation. Given a HPWS is comprised of motivation-enhancing practices often associated with encouraging those performance targets, such as incentive based pay and promotion (Wood, 2011), line managers will be more motivated to implement those voice mechanisms designed as part of the HPWS and to encourage voice that can contribute to their team's performance targets. Within a HPWS, line managers will also have greater opportunities to solicit voice and genuinely respond to issues, suggestions and concerns raised by their employees, as they have access to embedded formal voice mechanisms which they can implement within their own teams and which provide the line manager with the opportunity to escalate issues to higher levels of the organization (Mowbray, 2018).

Following on from this, through the HPWS' AMO-enhancing HR practices, managerial self-efficacy (Fast et al., 2014) can be improved, thus improving the line manager's ability to effectively manage voice and ability to provide a supportive environment for voice behaviours. Research on leaders and employee voice have shown there are a number of leadership behaviours that can signal to employees their supervisor is supportive of voice and which contribute to employee perceptions of voice safety and efficacy (Morrison and Milliken, 2000; Detert and Burris, 2007). For example, ethical and authentic leadership have been identified as contributing to psychological safety to speak up (Walumbwa and Schaubroeck, 2009), empowerment (Walumbwa et al., 2010), higher levels of leader-member exchange (LMX) quality and evidence of procedural justice (Hsiung, 2012). By empowering and consulting their employees and soliciting suggestions from them (Gao et al., 2011; Tangirala and Ramanujam, 2012) 
as well as acting on this input from below (Detert and Burris, 2007), this creates a voice climate whereby employees will perceive their manager has given them an opportunity to voice.

When line managers have the AMO to effectively manage voice and thus exhibit these supportive voice leadership behaviours, this in turn can impact their employees' AMO by increasing the employees' opportunities to voice, through the encouragement and solicitation of voice within the formal and informal voice channels. Likewise, through line managers exhibiting coaching and mentoring behaviours, skills associated with the successful implementation of HPWS (Jyoti and Rani, 2019), the employees' ability to voice could be improved (Detert and Burris, 2007). When the line manager exhibits distributive and procedural justice with respect to the administering of rewards and recognition, key practices within a HPWS (Karadas and Karatepe, 2019), the employees' motivation may be activated (Tyler, 1994). Likewise, when line managers empower their employees, commonly associated with HPWS continuous improvement and decision-making practices (van Assen, 2020), this can activate intrinsic motivation and lead to a prosocial motivation to voice (Raub and Robert, 2010; Frazier and Fainschmidt, 2012; Wang et al., 2016).

Therefore, we propose that the practices associated with the HPWS will enhance the line manager's AMO to manage employee voice and to develop leadership behaviours that are supportive of voice, such that line manager AMO will be positively related to the employees' AMO to voice and their subsequent voice behaviour.

\section{Employee AMO}


Next, we propose the practices associated with the HPWS will enhance employees' AMO to voice. Voice mechanisms such as self-managed teams, continuous improvement groups and suggestion schemes will provide employees with clear and unambiguous opportunities to then engage in voice behaviour. Mechanisms such as these are designed to encourage high levels of involvement and voice (Birdi et al., 2008), at the team or organizational level. Voice mechanisms, such as grievance procedures or indirect mechanisms such as committees, will enhance procedural justice and downward information sharing, and the latter can provide opportunities to be involved in decision making (Heffernan and Dundon, 2016). This signals to the employee they are respected and valued (Colvin, 2006), hence encouraging employee attitudes to voicing (Wood and de Menezes, 2011).

The ability-enhancing HR practices will also have a positive effect on employees' voicing behaviour. Selective recruitment can be used to select employees who have a greater propensity to voice, such as those with conscientiousness and extraversion personality attributes, which are antecedents to voice behaviour (LePine and Van Dyne, 2001). Practices such as training and coaching can be utilized to improve employees' ability to voice and to influence employees' attitudes to voicing (Boselie, 2010). Additionally, HPWS practices can improve employees' knowledge concerning work tasks and the organization and enhance their ability to identify issues to voice on (Lawler, 1986). For example, information sharing forums can improve an employee's ability to engage in voice behaviour, as the employee will have greater knowledge of the organization's strategy and can thus frame their voice to ensure the issue is aligned with that strategy (Wilkinson et al., 2013). 
Another route to voice using the AMO framework is that the HPWS will encourage an employees' pro-social motivation to voice and the enactment of voice that benefits others. Gittel et al. (2010) found the design of work teams within HPWS organizations enables greater employee-employee interaction i.e. relational coordination, when employees are involved in cross-functional teams. These authors suggest that this relational coordination provides a pathway to performance through the creation of an organizational climate where employees are motivated to act in the best interests of the organization. Other HR practices within the HPWS may also fuel voice motivations and subsequent behaviour. For example, Dysvik and Kuvaas (2008) found employees' perceptions of training and development opportunities were positively related to OCB's. Using social exchange theory, they explain this occurrence due to employee perceptions they are valued, which triggers their motivation to reciprocate with their employer. Hence, an OCB such as voice, is likely to be triggered by these HPWS motivation-enhancing HR practices.

Extrinsic rewards, such as performance pay, also provide a motivation to voice (Gerhart and Fang, 2015). Within a HPWS workplace, collective forms of performance pay based on groups or teams will be more prevalent (Wood and de Menezes, 2011) and effective compensation bundles such as profit-sharing, group performance pay and employee stock ownership are often used (Laroche and Salesina, 2017). Shared perceptions that the organization is supportive of voice and rewards performance will subsequently enhance an employee's pro-social motivation to speak up (Sun et al., 2007).

Therefore, we propose it is not just the opportunity to voice through the voice mechanisms that leads to voice behaviour. Rather, it is also the ability-enhancing and 
motivation-enhancing HR practices which cumulatively may influence employees' behaviours and their inclination to voice.

\section{Optimising employee voice under a HPWS}

We have theorized how mutual gains ER creates a positive climate for HPWS and the full range of voice behaviour, including content that will be associated with both employer and employee interests. Our discussion has theorized that a combination of AMO-enhancing practices within the HPWS practices will amplify voice behaviour through their influence over both line managers and employees. Given that line managers are key actors who implement formal voice mechanisms and provide a supportive environment where both formal and informal voice can flourish (Townsend and Mowbray, 2020), the line managers' AMO to unlock the voice of their employees will be paramount to employees expressing voice. Therefore, both the HPWS AMOenhancing practices and the line managers will signal to employees an expectation to voice on issues and concerns that may be associated with employer-interests, while the mutual gains ER will ensure that employees also have the AMO to voice on employee interests.

While our list of factors is not exhaustive, in summary of our model we identify the following main factors as contributing to the effectiveness of a HPWS in relation to voice behaviour: (1) an ER climate characterised by mutual gains; (2) line managers' AMO to implement the HWPS and display supportive voice leadership behaviours, which will be optimised through the HPWS; and (3) employees' AMO to express voice, optimised through the HPWS and line manager behaviours. 
We attest that such a model is something of an ideal type and there are other factors that may also contribute to the optimization of employee voice. Indeed, there is also the argument that the shift in responsibility in problem-solving and decision making from managers to employees might lead employees to perceive the HPWS practices as causing work intensification (Ramsay et al., 2000; Harley, 2005; Harley et al., 2010; Boxall and Macky, 2014) and expectations to engage in voice will not necessarily be seen as a positive experience by employees (Harley, 2020). While we recognize the complexities of voice, it is beyond the scope of this paper to consider all contingencies that may affect voice behaviour. What we have set out to do, however, is to use an integrated ER, HRM and OB lens to develop a model and theorize the ways in which both employee and employer interest voice can be encouraged within a HPWS.

\section{Practical implications}

At the outset, those organizations who have unions should be mindful of having cooperative union-employer relationships based on mutual gains that can contribute to the successful implementation of HPWS and subsequent line manager and employee voice behaviours (see Black and Lynch 2004). Given the AMO-enhancing voice effect will vary based on the how the HR practices have been implemented at the team level, organizations and leaders should ensure there is consistency in how the HR practices are implemented (Bowen and Ostroff, 2004). We have shown that HPWS practices can enhance the line managers' AMO to manage employee voice and to develop their ability to exhibit empowering and participative behaviours. Therefore, there should be consideration of including HR practices that build the knowledge, skills and ability of line managers to create supportive voice climates. Having appropriate policies in place that provide procedures for leaders responding to voice will also be important. For 
example, having an open-door policy and set response times that managers are required to acknowledge voice episodes, will encourage positive voicing behaviour (Blackburn and Rosen, 1993) and opportunities for voicing behaviour to occur. Organizations should encourage their managers to share important information and to provide autonomy to their employees (Holland et al., 2012).

We have illustrated how HR practices within a HPWS provide employees with greater AMO to engage in voice. When designing the HR system, organizations should consider those HR practices that enhance employee AMO to voice, such as selective recruitment, training, reward and recognition, and formal voice mechanisms. For example, selection methods could include peer evaluation whereby potential employees work alongside current employees in assessment centres to determine their ability to problem-solve and engage in continuous improvement (Blackburn and Rosen, 1993). Providing employees with training in communication, such as the use of critical language and assertion, can provide employees with greater confidence and ability to express voice and to raise challenging issues, thus improving voice efficacy (Okuyama, Wagner and Bijnen, 2014). Organizations will need to consider the most effective compensation and reward bundle that will motivate their employees to voice. For example, team performance pay may be the most optimal when job design is based around self-managing teams and continuous improvement performance goals are set at the team level (Laroche and Salesina, 2017).

We have also raised the issue that employees could perceive the HPWS as leading to work intensification. Increasing employees' perception that the expectation to voice is part of one's job role while ensuring that employees are engaged, will increase the likelihood that employees will express voice (Van Dyne et al., 2008; Rees et al., 2013). 
Ensuring that job resources, such as a supportive leader or training, offset the demands will be important to establishing this relationship, however (Demerouti et al., 2001).

Of course, one needs to be realistic in determining what practices any given organization should invest in, to ensure that performance is maximised while minimising waste (Meuer, 2017). As such, Van Rhee and Dul (2018) argue that consideration needs to be given to individual necessity and specific job requirements, which differs within organizations. They suggest spending resources on those factors that are currently limiting performance, such as motivation. On this basis, spending additional money on practices that provide opportunities to voice, for example, would be futile if motivation to voice is lacking. Consequently, to yield the greatest investment, priority should be given to practices that can enhance those factors which are currently limiting voice behaviour. This could give rise to new practices and the removal of others over the lifecycle of the HPWS and the differentiation of practices for individual employees.

\section{Implications for research}

The HPWS-voice behaviour model we have presented offers several directions for research, which could be quantitatively or qualitatively studied by HPWS or voice scholars across various disciplines. The model incorporates strands from ER, HRM and OB within the context of HPWS and offers opportunities for these researchers, who have hitherto ignored each other, to connect within this context. In addition to our proposed relationships, there is the need to examine what specific HR practices lead to an increase in line managers' AMO to implement and manage voice, and which ones will increase the AMO of employees to engage in voice behaviour. For example, longitudinal studies could be conducted to determine the effect of participative 
leadership training (Gao et al. 2011) on the line manager's ability to create a supportive team voice climate, encouraging either formal or informal voice behaviour. Future research which examines intrinsic and extrinsic motivators to voice, such as empowerment and contingent pay, could expand our understanding of what motivates employees to engage in different types of voice behaviour, such as individual, team or collective, or organization-focused or employee-focused.

Closer examination of the effect of ER on employee voice behaviour is warranted. For example, the extent to which a mutual gains climate increases individual and direct employee voice (rather than collective voice which is typically examined by ER scholars), provides a promising avenue to explore. There is the need to better understand the implications of working under a HPWS and whether perceptions of work intensification lead to silence or neglect on certain types of voice, such as employer-focused improvement-oriented voice, while at the same time leading to an increase in voice behaviour related to employee interests.

To conclude, our HPWS-voice behaviour interaction model has illustrated the routes through which employee voice can be optimised within a HPWS, through mutual gains ER and the AMO voice-enhancing practices. Our discussion of our model involved an integrated ER, HRM and OB lens to examine voice behaviour within a HPWS, which helps shed light on how HPWS HR practices not only provide opportunities to voice but also to enhance the ability and motivation of line managers to manage voice and for employees to express voice. Our theoretical model provides academics with suggested avenues for future research concerning how HR practices can encourage voice, while we also have provided practitioners with practical advice regarding the use of HR practices to maximize voice in their own organizations. 


\section{References}

Alfes, K., Veld, M., and Fürstenberg, N. (2020), “The relationship between perceived high-performance work systems, combinations of human resource well-being and human resource performance attributions and engagement", Human Resource Management Journal.

Allen, D. G., Shore, L. M. and Griffeth, R. W. (2003), "The role of perceived organizational support and supportive human resource practices in the turnover process", Journal of Management, Vol.29 No.1, pp.99-118.

Barry, M. and Wilkinson, A. (2016), "Pro-social or pro-management? A critique of the conception of employee voice as a pro-social behavior within organizational behavior", British Journal of Industrial Relations, Vol.54 No.2, pp.261-284.

Becker, B. and Gerhart, B. (1996), "The impact of human resource management on organizational performance: Progress and prospects", Academy of Management Journal, Vol.39 No.4, pp.779-801.

Becker, B. E. and Huselid, M. A. (1998), "High performance work systems and firm performance: A synthesis of research and managerial implications", Research in Personnel and Human Resources Journal, 16, pp.53-101.

Bergeron, D. M. (2007), “The potential paradox of organizational citizenship behavior: Good citizens at what cost?”, Academy of Management Review, Vol.32 No.4, pp.1078-1095.

Birdi, K., Clegg, C., Patterson, M., Robinson, A., Stride, C. B., Wall, T. D. and Wood, S. J. (2008), "The impact of human resource and operational management practices on company productivity: A longitudinal study", Personnel Psychology, Vol.61 No.3, pp.467-501. 
Black, S. E. and Lynch, L. M. (2004), "What's driving the new economy?: The benefits of workplace innovation", The Economic Journal, Vol.114 No.493, pp.F97-F116.

Blackburn, R. and Rosen, B. (1993), “Total quality and human resources management: lessons learned from Baldrige Award-winning companies", Academy of Management Perspectives, Vol.7 No.3, pp.49-66.

Blau, P. M. (1964), Exchange and Power in Social Life. Transaction Publishers.

Blumberg, M. and Pringle, C. D. (1982), “The missing opportunity in organizational research: Some implications for a theory of work performance", Academy of Management Review, Vol.7 No.4, pp.560-569.

Bolino, M. C. and Grant, A. M. (2016), "The bright side of being prosocial at work, and the dark side, too: a review and agenda for research on other-oriented motives, behavior, and impact in organizations", Academy of Management Annals, Vol.10 No.1, pp.599-670.

Boselie, P. (2010), "High performance work practices in the health care sector: a Dutch case study", International Journal of Manpower, Vol.31 No.1, pp.4258.

Bos-Nehles, A. C., Van Riemsdijk, M. J. and Kees Looise, J. (2013), “Employee perceptions of line management performance: applying the AMO theory to explain the effectiveness of line managers' HRM implementation", Human Resource Management, Vol.52 No.6, pp.861-877.

Bowen, D. E. and Ostroff, C. (2004), "Understanding HRM-firm performance linkages: The role of the "strength" of the HRM system", Academy of Management Review, Vol.29 No.2, pp.203-221. 
Boxall, P. and Macky, K. (2014), "High-involvement work processes, work intensification and employee well-being", Work, Employment \& Society, Vol.28 No.6, pp.963-984.

Boxall, P.F. and Purcell, J. (2011), Strategy and Human Resource Management. Basingstoke: Palgrave Macmillan.

Budd, J. W. (2004). Employment with a human face: Balancing efficiency, equity, and voice. Cornell University Press.

Budd, J. W., Gollan, P. J., and Wilkinson, A. (2010), "New approaches to employee voice and participation in organizations", Human Relations, Vol.63 No.3, pp.303-310.

Chamberlin, M., Newton, D. W. and Lepine, J. A. (2017), “A meta-analysis of voice and its promotive and prohibitive forms: Identification of key associations, distinctions, and future research directions", Personnel Psychology, Vol.70 No.1, pp.11-71.

Colvin, A. J. (2006), "Flexibility and fairness in liberal market economies: the comparative impact of the legal environment and high-performance work systems”, British Journal of Industrial Relations, Vol.44 No.1, pp.73-97.

Combs, J., Liu, Y., Hall, A. and Ketchen, D. (2006), "How much do high-performance work practices matter? A meta-analysis of their effects on organizational performanc”, Personnel psychology, Vol.59 No.3, pp.501-528.

Cook, H., MacKenzie, R., and Forde, C. (2017), “Union partnership as a facilitator to HRM: improving implementation through oppositional engagement", The International Journal of Human Resource Management, DOI: $\underline{10.1080 / 09585192.2017 .1399431}$ 
Demerouti, E., Bakker, A. B., Nachreiner, F. and Schaufeli, W. B. (2001), "The job demands-resources model of burnout", Journal of Applied Psychology, Vol.86 No.3, pp.499-512.

De Prins, P., Stuer, D. and Gielens, T. (2020), "Revitalizing social dialogue in the workplace: the impact of a cooperative industrial relations climate and sustainable HR practices on reducing employee harm", The International Journal of Human Resource Management, Vol.31 No.13, pp.1684-1704.

Detert, J. R. and Burris, E. R. (2007), "Leadership behavior and employee voice: Is the door really open?", Academy of Management Journal, Vol.50 No.4, pp.869884.

Dierdorff, E. C., Rubin, R. S. and Bachrach, D. G. (2012), "Role expectations as antecedents of citizenship and the moderating effects of work context", Journal of Management, Vol.38 No.2, pp573-598.

Do, H., Budhwar, P., \& Patel, C. (2019), "High-performance work system practices in Vietnam: a study of managers' perceptions", Journal of Organizational Effectiveness: People and Performance, Vol.6 No.3, pp.145-160.

Dysvik, A., \& Kuvaas, B. (2008), “The relationship between perceived training opportunities, work motivation and employee outcomes", International Journal of Training and Development, Vol.12 No.3, pp.138-157.

Elorza, U., Harris, C., Aritzeta, A., and Balluerka, N. (2016), "The effect of management and employee perspectives of high-performance work systems on employees' discretionary behaviour”, Personnel Review, Vol.45 No.1, pp.121141. 
Fast, N. J., Burris, E. R. and Bartel, C. A. (2014), "Managing to stay in the dark: Managerial self-efficacy, ego defensiveness, and the aversion to employee voice", Academy of Management Journal, Vol.57 No.4, pp.1013-1034.

Fenton-O'Creevy, M. (1998), "Employee involvement and the middle manager: evidence from a survey of organizations", Journal of Organizational Behavior, Vol.19 No.1, pp.67-84.

Fenton-O'Creevy, M. (2001), "Employee involvement and the middle manager: saboteur or scapegoat?”, Human Resource Management Journal, Vol.11 No.1, pp.24-40.

Frazier, M. L. and Fainshmidt, S. (2012), "Voice climate, work outcomes, and the mediating role of psychological empowerment: A multilevel examination”, Group \& Organization Management, Vol.37 No.6, pp.691-715.

Gao, L., Janssen, O. and Shi, K. (2011), "Leader trust and employee voice: The moderating role of empowering leader behaviors", The Leadership Quarterly, Vol.22 No.4, pp.787-798.

Gerhart, B., \& Fang, M. (2015). Pay, intrinsic motivation, extrinsic motivation, performance, and creativity in the workplace: Revisiting long-held beliefs. Annu. Rev. Organ. Psychol. Organ. Behav., Vol.2 No.1, pp.489-521.

Gill, C. (2009), "Union impact on the effective adoption of high performance work practices", Human Resource Management Review, Vol.19 No.1, pp.39-50.

Gill, C., \& Meyer, D. (2013), "Union presence, employee relations and high performance work practices", Personnel Review, Vol.42 No.5, pp.508-528.

Gittell, J. H., Seidner, R. and Wimbush, J. (2010), “A relational model of how highperformance work systems work", Organization Science, Vol.21 No.2, pp.490506. 
Gollan, P. J., Kaufman, B. E., Taras, D., and Wilkinson, A. (2015), Voice and Involvement At Work: Experience With Non-union Representation. New York, NY and Abingdon, Axon: Routledge.

Gouldner, A. W. (1960), "The norm of reciprocity: A preliminary statement", American Sociological Review, Vol.25 No.2, pp.161-178.

Guest, D. E. (1997), "Human resource management and performance: A review and research agenda", International Journal of Human Resource Management, Vol.8 No.3, pp.263-276.

Harley, B. (2005), "Hope or hype? High performance work systems", in B. Harley, J. Hyman and P. Thompson (eds.), Participation and Democracy at Work: Essays in Honour of Harvey Ramsay, Basingstoke: Palgrave, pp.38-54.

Harley, B. (2020), "High performance work systems and employee voice", in A. Wilkinson, J. Donaghey, T. Dundon and R. Freeman (eds.), The Handbook of Research on Employee Voice (2 ${ }^{\text {nd }}$ ed), London: Edward Elgar Press, pp.313327.

Harley, B., Sargent, L. and Allen, B. (2010), "Employee responses to 'high performance work system practices: An empirical test of the disciplined worker thesis", Work, Employment \& Society, Vol.24 No.4, pp.740-760.

Hewett, R., Shantz, A., Mundy, J. and Alfes, K. (2017), “Attribution theories in Human Resource Management research: a review and research agenda", The International Journal of Human Resource Management, Vol.29 No.1, pp.87126.

Holland, P., Cooper, B. K., Pyman, A. and Teicher, J. (2012), “Trust in management: the role of employee voice arrangements and perceived managerial opposition to unions", Human Resource Management Journal, Vol.22 No.4, pp.377-391. 
Holland, P., Cooper, B. and Sheehan, C. (2017), "Employee Voice, Supervisor Support, and Engagement: The Mediating Role of Trust", Human Resource Management, Vol.56 No.6, pp.915-929.

Hsiung, H. H. (2012), “Authentic leadership and employee voice behavior: A multilevel psychological process", Journal of Business Ethics, Vol.107 No.3, pp.349361.

Hu, X., \& Jiang, Z. (2018), “Employee-oriented HRM and voice behavior: a moderated mediation model of moral identity and trust in management", The International Journal of Human Resource Management, Vol.29 No.5, pp.746-771.

Huselid, M. A. (1995), “The impact of human resource management practices on turnover, productivity, and corporate financial performance", Academy of Management Journal, Vol.38 No.3, pp.635-672.

Jiang, K., Lepak, D.P., Han, K., Hong, Y., Kim, A. and Winkler, A.L. (2012), "Clarifying the construct of human resource systems: Relating human resource management to employee performance", Human Resource Management Review, Vol.22 No.2, pp.73-85.

Jo, H., Aryee, S., Hsiung, H. H. andGuest, D. (2020), "Fostering mutual gains: Explaining the influence of high-performance work systems and leadership on psychological health and service performance”, Human Resource Management Journal, Vol.30 No.2, pp.98-225.

Jyoti, J., and Rani, A. (2019), "Role of burnout and mentoring between high performance work system and intention to leave: Moderated mediation model", Journal of Business Research, Vol.98, pp.166-176. 
Karadas, G. and Karatepe, O.M. (2019), "Unraveling the black box: The linkage between high-performance work systems and employee outcomes", Employee Relations, Vol.41 No.1, pp.67-83.

Kaufman, B. E. (2015a), “Theorising determinants of employee voice: an integrative model across disciplines and levels of analysis", Human Resource Management Journal, Vol.25 No.1, pp.19-40.

Kaufman, B. E. (2015b), “Employee involvement and voice at Delta Air Lines: The leading edge of American practice”, in Gollan, P. J., Kaufman, B. E., Taras, D., and Wilkinson, A. (eds), Voice and Involvement at Work: Experience With Nonunion Representation. New York, NY and Abingdon, Axon: Routledge, pp.295340.

Kehoe, R. R. and Wright, P. M. (2013), “The impact of high-performance human resource practices on employees' attitudes and behaviors", Journal of Management, Vol.39 No.2, pp.366-391.

Knoll, M. and Redman, T. (2016), "Does the presence of voice imply the absence of silence? The necessity to consider employees' affective attachment and job engagement”, Human Resource Management, Vol.55 No.5, pp.829-844.

Knoll, M., Wegge, J., Unterrainer, C., Silva, S. and Jønsson, T. (2016), “Is our knowledge on voice and silence in organizations growing? Building bridges and (re)discovering opportunities", German Journal of Human Resource Management, Vol.30 No.3-4, pp.161-194.

Kroon, B., van de Voorde, K. and van Veldhoven, M. (2009), "Cross-level effects of high-performance work practices on burnout: Two counteracting mediating mechanisms compared", Personnel Review, Vol.38 No.5, pp.509-525. 
Kwon, B., Farndale, E. and Park, J. G. (2016), “Employee voice and work engagement: Macro, meso, and micro-level drivers of convergence?", Human Resource Management Review, Vol.26 No.4, pp.327-337.

Larsen, H.H. and Brewster C. (2003), "Line management responsibility for HRM: What is happening in Europe?", Employee Relations, Vol.25 No.3, pp.228-244. Lawler, E. E. (1986), High Involvement Management. San Francisco, CA: Jossey-Bass. LePine, J. A. and Van Dyne, L. (2001), "Voice and cooperative behavior as contrasting forms of contextual performance: evidence of differential relationships with big five personality characteristics and cognitive ability", Journal of Applied Psychology, Vol.86 No.2, pp.326-336.

Laroche, P. and Salesina, M. (2017), "The Effects of Union and Nonunion Forms of Employee Representation on High-Performance Work Systems: New Evidence from French Microdata", Human Resource Management, Vol.56 No.1, pp.173189.

MacDuffie, J. P. (1995), "Human resource bundles and manufacturing performance: Organizational logic and flexible production systems in the world auto industry", ILR Review, Vol.48 No.2, pp.197-221.

MacKenzie, R., Forde, C., Cook, H., and Valizade, D. (2015), "The effect of trade unions on High Performance Work Systems (HPWS): Assessing the impact of trade union power and the mediating role of industrial relations climate", Conference proceedings from $17^{\text {th }}$ ILERA World Conference, Cape Town, South Africa, 7-11 September 2015.

McGovern, P., Gratton, L., Hope-Hailey, V., Stiles, P. and Truss, C. (1997), "Human resource management on the line?", Human Resource Management Journal, Vol.7 No.4, pp.12-29. 
Marchington, M. (2007), "Employee voice systems", in Boxall, P., Purcell, J., and Wright, P. (eds.), The Oxford Handbook of Human Resource Management, Oxford: Oxford University Press, pp.231-250.

Meuer, J. (2017), "Exploring the Complementarities Within High-Performance Work Systems: A Set-Theoretic Analysis of UK Firms", Human Resource Management, Vol.56 No.4, pp.651-672.

Morrison, E. W. (1994), "Role definitions and organizational citizenship behavior: The importance of the employee's perspective", Academy of Management Journal, Vol.37 No.6, pp.1543-1567.

Morrison, E. W. (2011), "Employee voice behavior: Integration and directions for future research", The Academy of Management Annals, Vol.5 No.1, pp.373412.

Morrison, E. W. (2014), "Employee voice and silence", The Annual Review of Organizational Psychology and Organizational Behavior, Vol.1 No.1, pp.173197.

Morrison, E. W. and Milliken, F. J. (2000), “Organizational silence: A barrier to change and development in a pluralistic world", Academy of Management Review, Vol.25 No.4, pp.706-725.

Mowbray, P. K. (2018), “Giving a voice to managers: forging the desire line through the creation of informal employee voice channels and productive resistance", The International Journal of Human Resource Management, Vol.29 No.5, pp.941-969.

Mowbray, P. K., Wilkinson, A. and Tse, H. H. M. (2015), “An integrative review of employee voice: Identifying a common conceptualization and research agenda”, International Journal of Management Reviews, Vol.17 No.3, pp.382-400. 
Newman, A., Cooper, B., Holland, P., Miao, Q., \& Teicher, J. (2019), "How do industrial relations climate and union instrumentality enhance employee performance? The mediating effects of perceived job security and trust in management”, Human Resource Management, Vol.58 No.1, pp.35-44.

Nishii, L. H., Lepak, D. P. and Schneider, B. (2008), "Employee attributions of the "why" of HR practices: Their effects on employee attitudes and behaviors, and customer satisfaction", Personnel Psychology, Vol.61 No.3, pp.503-545.

Okuyama, A., Wagner, C. and Bijnen, B. (2014), "Speaking up for patient safety by hospital-based health care professionals: a literature review", BMC health services research, Vol.14, No.1, pp1-8.

Pohler, D.M. and Luchak, A.A. (2014), “The missing employee in employee voice research", in A. Wilkinson, J. Donaghey, T. Dundon and R. Freeman (eds.), The Handbook of Research on Employee Voice. London: Edward Elgar Press, pp.188-207.

Purcell, J. and Hutchinson, S. (2007), "Front-line managers as agents in the HRMperformance causal chain: theory, analysis and evidence", Human Resource Management Journal, Vol.17 No.1, pp.3-20.

Pyman, A., Cooper, B., Teicher, J. and Holland, P. (2006), “A comparison of the effectiveness of employee voice arrangements in Australia", Industrial Relations Journal, Vol.37 No.5, pp.543-559.

Pyman, A., Holland, P., Teicher, J., \& Cooper, B. K. (2010), "Industrial relations climate, employee voice and managerial attitudes to unions: An Australian study", British Journal of Industrial Relations, Vol.48 No.2, pp.460-480. 
Ramsay, H., Scholarios, D. and Harley, B. (2000), “Employees and high-performance work systems: testing inside the black box", British Journal of Industrial Relations, Vol.38 No.4, pp.501-531.

Raub, S. and Robert, C. (2010), "Differential effects of empowering leadership on inrole and extra-role employee behaviors: Exploring the role of psychological empowerment and power values", Human Relations, Vol.63 No.11, pp.17431770.

Rees, C., Alfes, K. and Gatenby, M. (2013), "Employee voice and engagement: Connections and consequences", The International Journal of Human Resource Management, Vol.24 No.14, pp.2780-2798.

Saridakis, G., Lai, Y. and Johnstone, S. (2017). "Does workplace partnership deliver mutual gains at work?", Economic and Industrial Democracy, $0143831 X 17740431$.

Siddique, M., Procter, S., \& Gittell, J. H. (2019), “The role of relational coordination in the relationship between high-performance work systems (HPWS) and organizational performance", Journal of Organizational Effectiveness: People and Performance, Vol.6 No.4, pp.246-266.

Sun, L. Y., Aryee, S. and Law, K. S. (2007), "High-performance human resource practices, citizenship behavior, and organizational performance: A relational perspective”, Academy of Management Journal, Vol.50 No.3, pp.558-577.

Tangirala, S. and Ramanujam, R. (2012), “Ask and you shall hear (but not always): Examining the relationship between manager consultation and employee voice", Personnel Psychology, Vol.65 No.2, pp.251-282. 
Tyler, T. R. (1994), "Psychological models of the justice motive: Antecedents of distributive and procedural justice", Journal of Personality and Social Psychology, Vol.67 No.5, pp.850-863.

van Assen, M. F. (2020), “Empowering leadership and contextual ambidexterity-The mediating role of committed leadership for continuous improvement”, European Management Journal, Vol.38 No.3, pp.435-449.

Van Dyne, L., Kamdar, D. and Joireman, J. (2008), "In-role perceptions buffer the negative impact of low LMX on helping and enhance the positive impact of high LMX on voice”, Journal of Applied Psychology, Vol.93 No.6, pp.11951207.

Van Waeyenberg, T. and Decramer, A. (2018), "Line managers' AMO to manage employees' performance: the route to effective and satisfying performance management", The International Journal of Human Resource Management, Vol.29 No.2, pp.3093-3114.

Vernon, G., and Brewster, C. (2013), “Structural spoilers or structural supports? Unions and the strategic integration of HR functions", The International Journal of Human Resource Management, Vol.24 No.6, pp.1113-1129.

Vigoda-Gadot, E. (2006), “Compulsory citizenship behavior: Theorizing some dark sides of the good soldier syndrome in organizations", Journal for the Theory of Social Behavior, Vol.36 No.1, pp.77-93.

Vigoda-Gadot, E. (2007), "Redrawing the boundaries of OCB? An empirical examination of compulsory extra-role behavior in the workplace", Journal of Business and Psychology, Vol.21 No.3, pp.377-405.

Walumbwa, F. O. and Schaubroeck, J. (2009), "Leader personality traits and employee voice behavior: mediating roles of ethical leadership and work group 
psychological safety", Journal of Applied Psychology, Vol.94 No.5, pp.12751286.

Walumbwa, F. O., Wang, P., Wang, H., Schaubroeck, J. and Avolio, B. J. (2010), "Psychological processes linking authentic leadership to follower behaviors", The Leadership Quarterly, Vol.21 No.5, pp.901-914.

Wang, D., Gan, C. and Wu, C. (2016), "LMX and employee voice: A moderated mediation model of psychological empowerment and role clarity", Personnel Review, Vol.45 No.3, pp.605-615.

Watson, S., Maxwell, G. A. and Farquharson, L. (2006), "Line managers' views on adopting human resource roles: The case of Hilton (UK) hotels', Employee Relations, Vol.29 No.3, pp.30-49.

Wilkinson, A., Barry, M., \& Morrison, E. (2020). Toward an integration of research on employee voice. Human Resource Management Review. doi: 10.1016/j.hrmr.2018.11.002

Wilkinson, A., Dundon, T., Donaghey, J. and Freeman, R. (2014), “Employee voice: Charting new terrain", in A. Wilkinson, J. Donaghey, T. Dundon and R. Freeman (eds.), The Handbook of Research on Employee Voice. London: Edward Elgar Press, pp.3- 16.

Wilkinson, A. Dundon, T. and Marchington, M. (2013), "Employee involvement and voice", in Bach, S. and Edwards, M. (eds.), Managing Human Resources (5 $5^{\text {th }}$ edn). Chichester: Wiley-Blackwell, pp.744-761.

Wood, S. (2011), "High involvement management and performance", in A. Wilkinson, P. J. Gollan, M. Marchington, and D. Lewin, D. (eds.), The Oxford handbook of participation in organizations. New York: Oxford University, pp.407-426. 
Wood, S., \& de Menezes, L. M. (2011), "High involvement management, highperformance work systems and well-being", The International Journal of Human Resource Management, Vol.22 No.7, pp.1586-1610.

Wood, S. J. and Wall, T. D. (2007), "Work enrichment and employee voice in human resource management-performance studies," The International Journal of Human Resource Management, Vol.18 No.7, pp.1335-1372.

Wu, W., Tang, F., Dong, X. and Liu, C. (2015), "Different identifications cause different types of voice: A role identity approach to the relations between organizational socialization and voice", Asia Pacific Journal of Management, Vol.32 No.1, pp.251-287. 